\section{DAMPAK LAYANAN INTERNET BANKING DALAM MENINGKATKAN KEPUASAN NASABAH}

\author{
Noviryantika \\ noviiryantika@gmail.com \\ STIE Indonesia Pontianak
}

Internet

Banking;

Service

Quality

\title{
ABSTRACT
}

Internet banking is currently a method of providing banking services to its customers. PT. Bank Bukopin uses Internet Banking technology in an effort to provide satisfaction to its customers. The purpose of this study was to determine the effect of efficiency, fulfillment, system availability, privacy, responsiveness, compensation and contact on the quality of internet banking services on customer satisfaction. The independent variable is the quality of internet banking services using 7 variable dimensions, while the dependent variable is customer satisfaction. The data analysis method uses multiple regression. The results showed that efficiency, fulfillment, system availability, responsiveness and compensation on the quality of internet banking services had a positive and significant effect on customer satisfaction at PT. Bank Bukopin Pontianak Branch. While privacy and contacts on the quality of internet banking services have a negative and significant impact on customer satisfaction of PT. Bank Bukopin Pontianak Branch.

Key word: internet banking, service quality, customer satisfaction

\section{PENDAHULUAN}

Internet Banking, ini termasuk saluran teranyar e-Banking yang memungkinkan nasabah melakukan transaksi via internet dengan menggunakan komputer/PC atau PDA. Fitur transaksi yang dapat dilakukan sama dengan Phone Banking yaitu informasi jasa/produk bank, informasi saldo rekening, transaksi pemindahbukuan antar rekening, pembayaran (kartu kredit, listrik, dan telepon), pembelian (voucher dan tiket), dan transfer ke bank lain. Kelebihan dari saluran ini adalah kenyamanan bertransaksi dengan tampilan menu dan informasi secara lengkap tertampang di layar komputer/PC atau PDA. Dari waktu ke waktu, makin banyak bank yang menyediakan layanan atau jasa internet banking yang diatur melalui Peraturan Bank Indonesia No. 9/15/PBI/2007 Tahun 2007 tentang Penerapan Manajemen Risiko Dalam Penggunaan Teknologi Informasi oleh Bank Umum. Penyelenggaraan Internet Banking merupakan penerapan atau aplikasi teknologi informasi yang terus berkembang dan dimanfaatkan untuk menjawab keinginan nasabah perbankan yang menginginkan servis cepat, aman, nyaman murah dan tersedia setiap saat (24 
Internet

Banking;

Service

Quality

jam/hari, 7 hari/minggu) dan dapat diakses dari mana saja baik itu dari HP, Komputer, laptop/ note book, PDA, dan sebagainya. (Wikipedia bahasa Indonesia, Ensiklopedia Bebas, 2011). Sedangkan menurut Sathye (1999). Internet banking dapat diartikan sebagai pengaturan pada halaman web oleh bank untuk memberikan informasi tentang produk dan jasa, namun pada tingkat lanjut akan melibatkan penyediaan fasilitas untuk mengakses rekening, transfer dana dan membeli produkproduk finansial atau layanan online, yang disebut sebagai transaksional online banking.

Berdasarkan hasil riset MARS Indonesia (14/02/2013) yang dimuat dalam "34\% Nasabah Sudah Melek Internet Banking". Berdasarkan hasil survei MARS belum lama ini terungkap bahwa dari 1.710 nasabah di 5 kota (Jakarta, Bandung, Semarang, Surabaya, Medan) yang disurvei, sebanyak 34,7\% menyatakan aware atau melek internet banking. Meski jumlah ini masih kalah dibandingkan dengan tingkat awareness mobile banking, tapi sudah ada tren peningkatan yang cukup signifikan. Sayangnya, tingkat awareness internet banking yang sudah lumayan tinggi, tidak diikuti dengan tingkat penetrasinya, yaitu baru mencapai 8,1\%. Masih ada 91,9\% nasabah yang belum menggunakan atau memiliki akun internet banking. Ini juga masih jauh lebih rendah dibandingkan dengan tingkat penetrasi mobile banking yang sudah mencapai $41,2 \%$. Tapi sebenarnya hal ini cukup wajar, mengingat jumlah pengguna handphone atau telepon genggam maupun smartphone yang lebih banyak daripada jumlah pengguna internet, meski belakangan akses internet via handphone (fasilitas data) sudah mulai marak. Masih rendahnya tingkat penetrasi layanan self service ini, salah satunya karena nasabah belum sepenuhnya merasa aman dari tindak kejahatan ataupun kesalahan sistem internet banking yang merugikan nasabah. Ketertutupan perbankan demi menjaga kredibilitas dan kepercayaan nasabah membuat kasus-kasus perampokan melalui internet banyak yang tidak dilaporkan kepada polisi.

Menurut Kotler dalam Tjiptono (2005): "Kualitas jasa harus dimulai dari kebutuhan pelanggan dan berakhir dengan kepuasan pelanggan serta persepsi positif terhadap kualitas jasa. Untuk mengevaluasi, dan memperbaiki kualitas layanan online, Zeithaml, et al., (2002) telah mengidentifikasi tujuh dimensi kualitas layanan online yaitu: efisiensi, reliabilitas, fulfillment, privasi, daya tanggap 
(responsiveness), kompensasi dan kontak (contact). Menurut Tjiptono (2008): Di antara sekian banyak model kualitas layanan online yang berkembang belakangan ini, tampaknya model yang paling komprehensif dan integratif adalah E-S-QUAL yang dikembangkan oleh Parasuraman, Zeithaml \& Malhotra (2005). Model yang menyempurnakan eSERVQUAL ini berfokus pada dua elemen utama: "core online service" dan "recovery online service': Masing-masing elemen dijabarkan lagi ke dalam beberapa dimensi. Core online service quality (E-S-QUAL) meliputi empat dimensi: (1) efisiensi (kemudahan dan kecepatan mengakses dan menggunakan situs perusahaan); (2) fulfilment (akurasi janji layanan, ketersediaan stok produk, dan pengiriman produk sesuai dengan waktu yang dijanjikan); (3) ketersediaan sistem (fungsionalitas teknis situs yang beroperasi sebagaimana mestinya); dan (4) privasi (tingkat keamanan situs dan proteksi terhadap informasi pelanggan). $E$ recovery service quality (E-RecS-QUAL) terdiri atas (1) responsivitas (penanganan masalah dan pengembalian produk secara efektif melalui mekanisme di situs bersangkutan), (2) kompensasi (sejauh mana situs bersangkutan mengompensasi pelanggan atas masalah yang terjadi); dan (3) kontak (ketersediaan bantuan via telepon atau staf online).

Kualitas yang rendah akan menimbulkan ketidakpuasan pada pelanggan, tidak hanya pelanggan tersebut tapi juga berdampak pada orang lain. Karena pelanggan yang kecewa akan bercerita paling sedikit kepada 15 orang lainnya. Dampaknya, calon pelanggan akan menjatuhkan pilihannya kepada pesaing (Lupiyoadi dan Hamdani, 2006). Kepuasan nasabah adalah kepuasan nasabah terhadap layanan intenet banking yang dirasakannya atau diterimanya, setelah membandingkan dengan layanan yang diharapkan. Pengukuran variabel ini menggunakan item pernyataan yang digunakan olah Rod et al. (2004) sebagai berikut: merasa puas terhadap layanan internet banking yang diterima, merasa puas terhadap transaksi berbasis internet yang diterima dan merasa puas terhadap produk/jasa yang ditawarkan melalui internet Banking

Bank Bukopin adalah bank yang menfokuskan diri pada segmen UMKMK, saat ini telah tumbuh dan berkembang menjadi bank yang masuk ke kelompok bank menengah di Indonesia dari sisi aset. Bank Bukopin sejak tahun 1996, sistem realtime on-line juga telah menghubungkan lebih dari 400 Kantor dan 347 ATM Bank 
Internet

Banking;

Service

Quality

\section{4}

Bukopin di seluruh Nusantara. Kesiapan teknologi juga menunjang layanan bisnis konsumer melalui fasilitas perbankan on-line seperti internet banking. Sedangkan dari segi sistem pengendali, juga telah dikembangkan kerangka pengendalian risiko, termasuk checks and balances, yang dibutuhkan dalam pengembangan dan pelaksanaan layanan bisnis konsumer yang melibatkan begitu banyak transaksi dan nasabah dalam kegiatan sehari-harinya. (annual report PT. Bank Bukopin, Tbk, 2012).

Hingga akhir tahun 2018, Bank Bukopin telah memiliki jaringan layanan yang terdiri dari 40 Kantor Cabang, 114 Kantor Cabang Pembantu, 87 Kantor Fungsional, 147 Kantor Kas dan 39 Payment Point yang tersebar di 22 provinsi di Indonesia. Selain itu, Bank Bukopin juga memiliki 620 ATM Bukopin, selain terhubung dengan lebih dari 30.000 ATM pada jaringan nasional, jaringan Plus, serta Visa Internasional di seluruh dunia (annual report PT. Bank Bukopin, Tbk, 2018).

PT. Bank Bukopin Cabang Pontianak mengalami kenaikan nasabah dari tahun ke tahun, pada tahun 2016 jumlah nasabah sebesar naik sebesar 6,62 persen, pada tahun 2017 jumlah nasabah sebesar naik sebesar 7,39 persen, pada tahun 2018 jumlah nasabah sebesar naik kembali sebesar 8,37 persen. Peningkatan jumlah nasabah ini membuktikan Bank Bukopin telah melangkah ke depan untuk menjadi salah satu bank ritel terkemuka di Indonesia secara umum dan di Kota Pontianak secara khususnya. Kini Bank Bukopin senantiasa melayani setiap pengaduan nasabah sepanjang 24 jam. Penanganan atas setiap pengaduan terkait masalah kartu kredit, ATM, SMS Banking, dan Internet Banking, ditanggapi menggunakan SMS blasting dalam waktu 1 x 24 jam.

Berdasarkan latar belakang yang telah diuraikan di atas maka peneliti ingin mengetahui seberapa besar pengaruh kualitas layanan internet banking terhadap kepuasan nasabah PT. Bank Bukopin Cabang Pontianak. Penelitian ini menggunakan variabel kepuasan konsumen PT. Bank Bukopin Pontianak sebagai variabel dependen. Sedangkan untuk variabel independennya, penelitian ini menggunakan variabel kualitas layanan internet banking pada PT. Bank Bukopin Cabang Pontianak (efficiency, fulfillment, ketersediaan sistem, privacy, responsive, kompensasi dan kontak). 
Berdasarkan pada latar belakang, maka yang menjadi permasalahan dalam penelitian ini adalah:

1. Apakah ada pengaruh efficiency pada kualitas layanan internet banking terhadap Banking; kepuasan nasabah PT. Bank Bukopin Cabang Pontianak?

2. Apakah ada pengaruh fulfillment pada kualitas layanan internet banking terhadap kepuasan nasabah PT. Bank Bukopin Cabang Pontianak?

3. Apakah ada pengaruh ketersediaan sistem pada kualitas layanan internet banking terhadap kepuasan nasabah PT. Bank Bukopin Cabang Pontianak?

4. Apakah ada pengaruh privacy pada kualitas layanan internet banking terhadap kepuasan nasabah PT. Bank Bukopin Cabang Pontianak?

5. Apakah ada pengaruh responsivitas pada kualitas layanan internet banking terhadap kepuasan nasabah PT. Bank Bukopin Cabang Pontianak?

6. Apakah ada pengaruh kompensasi pada kualitas layanan internet banking terhadap kepuasan nasabah PT. Bank Bukopin Cabang Pontianak?

7. Apakah ada pengaruh kontak pada kualitas layanan internet banking terhadap kepuasan nasabah PT. Bank Bukopin Cabang Pontianak?

\section{TINJAUAN TEORITIS}

\section{Data Empiris}

Penelitian Parmita Saha dan Yanni Zhao (2005) Relationship between online service quality and customer satisfaction Untuk mengetahui bagaimana hubungan antara kualitas layanan internet banking (efficiency, reliability, fulfillment, privacy, responsiveness, communication, personalization, technology update, logistic/technological equipment) terhadap kepuasan nasabah. Hasil penelitian menunjukkan bahwa kualitas Kualitas layanan internet banking mempunyai pengaruh yang kuat terhadap kepuasan nasabah.

Hasil penelitian Yusnaini (2009) Pengaruh kualitas pelayanan internet banking Terhadap kepuasan dan loyalitas konsumen pada bank swasta Untuk mengkaji mutu internet banking terhadap kepuasan pelanggan Hasilnya menunjukkan bahwa kualitas internet banking dapat mempengaruhi kepuasan pelanggan.

Hasil penelitian Khan dan Mahapatra (2009) Service quality evaluation in internet banking: an empirical study in India. Untuk mengkaji kualitas layanan 
Internet

Banking;

Service

Quality

internet banking (ibanking) di India dengan menggunakan 7 dimensi kualitas layanan reliability, accessibility, userfriendliness, privacy/security, efficiency, responsiveness dan fulfillment. Hasil menunjukkan bahwa pelanggan puas dengan 5 dimensi kualitas layanan reliability, accessibility, privacy/security, responsiveness danfulfillment. Tetapi tidak puas dengan dimensi userfriendliness (berdasarkan tingkat pentingnya kualitas layanan) sehingga dimensi tersebut menjadi rekomendasi perbaikan bagi bank dan berdasarkan hasil analisis regresi, dimensi privacy dan fulfillment merupakan dimensi yang tidak memuaskan nasabah sehingga hal tersebut menjadikan bank gagal memberikan layanan yang memuaskan pada dimensi tersebut.

Hasil penelitian Jajuk Herawati dan Prayekti ( 2011) Pengaruh dimensi internet banking service quality dan kepercayaan nasabah terhadap kepuasan nasabah. Terdapat pengaruh yang positif antara dimensi internet banking service quality (IBSQ) yang meliputi online customer service (X1), online system information quality (X2), dan banking service product quality (X3) serta Kepercayaan nasabah (X4) terhadap Kepuasan nasabah internet banking (Y).

Hasil penelitian Siti Monalisa dan Erma Suryani (2013) Pengaruh kualitas layanan internet banking Terhadap kepuasan dan loyalitas nasabah bank dengan menggunakan sistem dinamik. Untuk membangun model umum sistem simulasi dalam mempertahankan dan meningkatkan kepuasan dan loyalitas nasabah bank melalui kualitas layanan internet banking serta menghasilkan skenario terbaik yang dapat digunakan oleh pembuat kebijakan dalam mempertahankan dan meningkatkan kepuasan dan loyalitas nasabah bank melalui kualitas layanan internet banking dimensi kualitas layanan : efficiency, reliability, responsiveness, privacy, security dan fulfillment dapat meningkatkan kepuasan dan loyalitas nasabah jika ditingkatkan sebanyak $80 \%$ untuk setiap dimensi

Hasil penelitian Fifip Chopipah O (2010) Pengaruh kualitas layanan internet banking Klik BCA terhadap kepuasan nasabah. Hasil pengujian menunjukkan bahwa $65,8 \%$ kepuasan nasabah dapat dijelaskan oleh variabel kualitas layanan internet banking dengan dimensi efficiency, fulfillment, reliability, dan privacy, artinya $34,2 \%$ dipengaruhi oleh variabel lain, yang tidak dalam cakupan penelitian penulis. 


\section{Kualitas Jasa}

Menurut Kotler dalam Tjiptono (2005) Kualitas jasa harus dimulai dari kebutuhan pelanggan dan berakhir dengan kepuasan pelanggan serta persepsi positif terhadap kualitas jasa. Menurut Tjiptono (2005) kualitas jasa merupakan suatu kondisi dinamis yang berhubungan dengan produk, jasa, manusia, proses dan lingkungan yang memenuhi harapan. Dari beberapa penjelasan diatas, maka Quality dapat disimpulkan bahwa kualitas jasa adalah sesuatu yang dipahami sebagai nilai yang dapat memuaskan, memenuhi kebutuhan, dan harapan pelanggan.

Terbentuknya harapan atas kualitas pelayanan (expected service) dari para pelanggan dipengaruhi oleh berbagai kegiatan marketing seperti iklan / promosi, penjualan, harga, tradisi, maupun adanya kontrak konsumen dengan pemberi pelayanan sebelumnya. Sementara itu, pelayanan yang diterima banyak dipengaruhi oleh kontak antar personal dengan pembeli pelayanan, fasilitas fisik, prosedur yang merupakan bagian dari sistem pelayanan.

\section{Kualitas Jasa Online}

a. Model Kualitas Jasa Online

Model yang paling komprehensif dan integratif adalah model eSERVQUAL yang dikemukakan oleh Zeithaml, et al,. (2002). Pada prinsipnya, model ini merupakan adaptasi dan perluasan model tradisional SERVQUAL ke konteks berbelanja online. Dalam model e-SERVQUAL terdapat empat macam gap, yaitu information gap, design gap, communication gap, dan fulfillment gap. Perbedaan persepsi antara perusahaan dengan pelanggan dalam wujud kualitas layanan online dapat menimbulkan kompleksitas dalam menentukan kualitas layanan online.

Kompleksitas ini dapat menimbulkan kesenjangan/gap antara layanan online yang diharapkan dengan yang diterima pelanggan. Zeithaml, et al. (2002) dalam Tjiptono (2006) mengidentifikasi empat gap yang menyebabkan perbedaan persepsi mengenai kualitas layanan online, yaitu: Information gap, design gap, communication gap dan fulfillment gap. Dengan kata lain, tipe gap ini disebabkan communication gap, misalnya pemasaran menjanjikan jaminan uang kembali, namun kenyataannya website perusahaan tidak 


\section{Internet}

Banking;

Service

Quality

038

memiliki back-end infrastructure untuk menerima dan memproses komplain dari para pelanggan yang tidak puas. Tipe kedua adalah frustasi disebabkan kelemahan dalam desain dan operasi website, misalnya pelanggan tidak bisa merampungkan transaksi pembelian elektronik. Tipe ini dikarenakan dampak kumulatif dari information gap dan desain gap.

b. Dimensi Kualitas Jasa Online

Menurut Tjiptono (2008): Ada tujuh dimensi e-SQ atau eSERVQUAL: efisiensi, reliabilitas, fulfillment, privasi, daya tanggap, kompensasi, dan kontak (Zeithaml, et al., 2002). Untuk mengevaluasi, dan memperbaiki kualitas layanan online, Zeithaml, et al., (2002) telah mengidentifikasi tujuh dimensi kualitas layanan online yaitu:

1) Efisiensi, yaitu kemampuan pelanggan untuk mengakses website, mencari produk yang diinginkan dan informasi yang berkaitan dengan produk tersebut, dan meninggalkan situs bersangkutan dengan upaya minimal.

2) Reliabilitas, berkenaan dengan fungsionalitas teknis situs bersangkutan, khususnya sejauh mana situs tersebut tersedia dan berfungsi sebagaimana mestinya.

3) Fulfillment, mencakup akurasi janji layanan, ketersediaan stok produk, dan pengiriman produk sesuai dengan waktu yang dijanjikan.

4) Privasi, berupa jaminan bahwa data perilaku berbelanja tidak akan diberikan kepada pihak lain manapun dan bahwa informasi kartu kredit pelanggan terjamin keamanannya.

5) Daya tanggap (responsiveness), merupakan kemampuan pergecer online untuk memberikan informasi yang tepat kepada pelanggan sewaktu timbul masalah, memiliki mekanisme untuk menangani pengembalian produk, dan menyediakan garansi online.

6) Kompensasi, meliputi pengembalian uang, biaya pengiriman, dan biaya penanganan produk.

7) Kontak (contact), mencerminkan kebutuhan pelanggan untuk bisa berbicara dengan staf layanan pelanggan secara online atau melalui telepon (dan bukan berkomlunikasi dengan mesin). 
Menurut Tjiptono (2008) bahwa "Di antara sekian banyak model kualitas layanan online yang berkembang belakangan ini, tampaknya model yang paling komprehensif dan integratif adalah E-S-QUAL yang dikembangkan oleh Parasuraman, Zeithaml \& Malhotra (2005). Model yang menyempurnakan eSERVQUAL ini berfokus pada dua elemen utama: "core online service" dan "recovery online service': Masing-masing elemen dijabarkan lagi ke dalam beberapa dimensi. Core online service quality (E-S-QUAL) meliputi empat dimensi: (1) efisiensi (kemudahan dan kecepatan mengakses dan menggunakan situs perusahaan); (2) fulfillment (akurasi janji layanan, ketersediaan stok produk, dan pengiriman produk sesuai dengan waktu yang dijanjikan); (3) ketersediaan sistem (fungsionalitas teknis situs yang beroperasi sebagaimana mestinya); dan (4) privasi (tingkat keamanan situs dan proteksi terhadap informasi pelanggan). $E$ recovely service quality (E-RecS-QUAL) terdiri atas (1) responsivitas (penanganan masalah dan pengembalian produk secara efektif melalui mekanisme di situs bersangkutan), (2) kompensasi (sejauh mana situs bersangkutan mengompensasi pelanggan atas masalah yang terjadi); dan (3) kontak (ketersediaan bantuan via telepon atau staf online).

Berdasarkan uraian di atas dapat disimpulkan dalam dimensi-dimensi dalam kualitas layanan online dimaksudkan untuk mengetahui kualitas layanan online yang diberikan serta sebagai sarana untuk mengevaluasi dan sekaligus memperbaiki kualitas layanan online yang diberikan.

\section{Kepuasan Pelanggan}

Menurut Kotler \& Armstrong (2010), kepuasan pelanggan adalah dilihat dari sejauh mana kinerja suatu produk yang dirasakan cocok dengan harapan pembeli sehingga dapat menimbulkan perasaan senang atau kecewa pada seorang pembeli. Perasaan senang atau kecewa seseorang yang muncul setelah membandingkan kinerja (hasil) produk yang dipikirkan terhadap (atau hasil) yang diharapkan. Jika kinerja berada dibawah harapan, pelanggan merasa tidak puas akan tetapi jika kinerja melebihi harapan maka pelanggan akan sangat senang atau puas (Kotler \& Keller, 2009).

Kepuasan nasabah adalah kepuasan nasabah terhadap layanan intenet banking yang dirasakannya atau diterimanya, setelah membandingkan dengan layanan 
Internet

Banking;

Service

Quality

040

yang diharapkan. Pengukuran variabel ini menggunakan item pernyataan yang digunakan olah Rod et al. (2004) sebagai berikut:

a. Saya merasa puas terhadap layanan internet banking yang saya terima.

b. Saya merasa puas terhadap transaksi berbasis internet yang saya terima.

c. Saya merasa puas terhadap produk/jasa yang ditawarkan melalui internet Banking

d. Penggunaan kartu kredit dapat meningkatkan prestige

\section{METODE PENELITIAN}

Jenis penelitian yang digunakan dalam penelitian ini adalah metode penelitian survei, instrument menggunakan kuesioner. Obyek penelitian adalah nasabah PT. Bank Bukopin Cabang Pontianak yang ada di Kota Pontianak. Populasi adalah seluruh nasabah PT. Bank Bukopin Cabang Pontianak. Tehnik penarikan sampling menggunakan accidental sampling sebanyak 100 responden. Adapun kriteria sampel dalam penelitian ini adalah nasabah yang pernah menggunakan layanan internet banking minimal 2 kali menggunakan fasilitas ini.

Teknik pengumpulan data dalam penelitian ini dilakukan dengan cara: (1) Observasi, pengamatan terhadap objek yang akan diteliti yang dilakukan secara langsung; (2) Dokumentasi, yaitu mempelajari dokumen yang berkaitan dengan seluruh data yang diperlukan dalam penelitian; (3) Wawancara, melakukan tanya jawab secara langsung dengan pihak-pihak yang terkait guna mendapatkan data dan keterangan yang menunjang analisis dalam penelitian; (3) Kuesioner, pengumpulan data dengan menyebarkan daftar pertanyaan pada responden.

Adapun variabel dalam penelitian merupakan kualitas layanan internet banking dan kepuasan nasabah.

Tabel 1 Operasional Variabel Penelitian

\begin{tabular}{|l|l|l|l|}
\hline Variabel & \multicolumn{1}{|c|}{ Dimensi } & \multicolumn{1}{c|}{ Defenisi } & \multicolumn{1}{c|}{ Indikator } \\
\hline Kualitas & Efficiency & Kemudahan dan & 1)Layanan situs internet mudah \\
Layanan & $\left(\mathrm{X}_{1}\right)$ & kecepatan & digunakan \\
Internet & & mengakses dan & 2)Layanan situs internet dapat \\
& & & diakses cepat \\
\cline { 2 - 4 } & & &
\end{tabular}




\begin{tabular}{|c|c|c|c|}
\hline \multirow[t]{3}{*}{$\begin{array}{l}\text { Banking } \\
\text { (X) }\end{array}$} & & $\begin{array}{l}\text { menggunakan situs } \\
\text { perusahaan }\end{array}$ & 3)Pengecekan saldo cepat \\
\hline & $\begin{array}{l}\text { Fulfillment } \\
\left(\mathrm{X}_{2}\right)\end{array}$ & $\begin{array}{l}\text { Akurasi janji } \\
\text { layanan, } \\
\text { ketersediaan produk, } \\
\text { dan pengiriman } \\
\text { sesuai waktu yang } \\
\text { dijanjikan }\end{array}$ & $\begin{array}{l}\text { 1)Layanan situs internet mudah } \\
\text { digunakan } \\
\text { 2)Layanan situs internet dapat } \\
\text { diakses cepat } \\
\text { 3)Pengecekan saldo cepat }\end{array}$ \\
\hline & $\begin{array}{l}\text { Ketersediaan } \\
\text { system }\left(\mathrm{X}_{3}\right)\end{array}$ & $\begin{array}{l}\text { Fungsionalitas } \\
\text { teknis situs yang } \\
\text { beroperasi } \\
\text { sebagaimana } \\
\text { mestinya }\end{array}$ & $\begin{array}{l}\text { 1)Layanan situs internet dapat } \\
\text { digunakan selama } 24 \text { jam dengan } \\
\text { lancer; 2)Layanan situs internet } \\
\text { bank dapat digunakan dimanapun; } \\
\text { 3)Sistem informasi layanan situs } \\
\text { internet selalu up to date }\end{array}$ \\
\hline & Privacy $\left(\mathrm{X}_{4}\right)$ & $\begin{array}{l}\text { Tingkat keamanan } \\
\text { situs dan proteksi } \\
\text { terhadap informasi } \\
\text { pelanggan }\end{array}$ & $\begin{array}{l}\text { 1)Transaksi pembayaran lewat } \\
\text { fasilitas internet banking dapat } \\
\text { dipercaya; 2)Fasilitas internet } \\
\text { banking mampu memproteksi } \\
\text { informasi pribadi nasabah; 3) } \\
\text { Fasilitas internet banking dapat } \\
\text { menjaga kerahasiaan PIN dan } \\
\text { password rekening nasabah }\end{array}$ \\
\hline & $\begin{array}{l}\text { Daya } \\
\text { tanggap } \\
\left(\mathrm{X}_{5}\right)\end{array}$ & $\begin{array}{l}\text { Penanganan masalah } \\
\text { dan pengembalian } \\
\text { produk secara } \\
\text { efektif melalui } \\
\text { mekanisme di situs } \\
\text { bersangkutan }\end{array}$ & $\begin{array}{l}\text { 1)Tanggap dalam memberikan } \\
\text { bantuan dan informasi yang tepat; } \\
\text { 2)Cepat tanggap dalam masalah } \\
\text { yang terjadi misalnya PIN dan } \\
\text { sebagainya; 3)Memiliki komitmen } \\
\text { dalam menyediakan garansi online }\end{array}$ \\
\hline & $\begin{array}{l}\text { Kompensasi } \\
\left(\mathrm{X}_{6}\right)\end{array}$ & $\begin{array}{l}\text { Sejauh mana situs } \\
\text { bersangkutan } \\
\text { mengkompensasi }\end{array}$ & $\begin{array}{l}\text { 1)Dapat melakukan pengembalian } \\
\text { uang dengan akurat dan transparan } \\
\text { jika terdapat diskon pembelian } \\
\text { ataupun pembatalan; }\end{array}$ \\
\hline
\end{tabular}

Internet

Banking;

Service

Quality

041 


\begin{tabular}{|c|c|c|c|c|}
\hline $\begin{array}{l}\text { Internet } \\
\text { Banking; } \\
\text { Service } \\
\text { Quality } \\
042\end{array}$ & & & $\begin{array}{l}\text { pelanggan atas } \\
\text { masalah yang terjadi }\end{array}$ & $\begin{array}{l}\text { 2)Memberikan biaya yang wajar } \\
\text { atas biaya online; 3)Situs internet } \\
\text { bank memberikan manfaat dan } \\
\text { kepraktisan untuk melakukan } \\
\text { interaksi dengan bank }\end{array}$ \\
\hline & & Kontak $\left(\mathrm{X}_{7}\right)$ & $\begin{array}{l}\text { Mencerminkan } \\
\text { ketersediaan } \\
\text { bantuan via telepon } \\
\text { atau staf online }\end{array}$ & $\begin{array}{l}\text { 1)Tidak sulit menerima layanan } \\
\text { kontak langsung melalui } \\
\text { telepon/online pada situs internet } \\
\text { bank; 2)Staf layanan online bank } \\
\text { mampu berkomunikasi dengan } \\
\text { baik; 3) Dipermudah untuk dapat } \\
\text { berbicara langsung dengan staf } \\
\text { layanan bank melalui telepon }\end{array}$ \\
\hline & $\begin{array}{l}\text { Kepuasan } \\
\text { Nasabah } \\
\text { (Y) }\end{array}$ & \multicolumn{2}{|c|}{$\begin{array}{l}\text { Perasaan senang atau kecewa } \\
\text { seseorang yang muncul setelah } \\
\text { membandingkan kinerja (hasil) } \\
\text { produk yang dipikirkan terhadap } \\
\text { (atau hasil) yang diharapkan }\end{array}$} & $\begin{array}{l}\text { 1)Merasa puas terhadap layanan } \\
\text { internet banking yang saya terima; } \\
\text { 2)Merasa puas terhadap transaksi } \\
\text { berbasis internet yang saya terima; } \\
\text { 3)Merasa puas terhadap } \\
\text { produk/jasa yang ditawarkan } \\
\text { melalui internet banking }\end{array}$ \\
\hline
\end{tabular}

Sumber : Parasuraman, Zeithaml \& Malhotra (2005) dan Rod Et Al (2004)

\section{Teknis analisis data}

Analisis data kuantiatif adalah analisis data yang menggunakan data berbentuk angka-angka yang diperoleh sebagai hasil pengukuran atau penjumlahan (Nurgiyantoro dkk, 2004). Untuk menjawab permasalahan berikutnya disesuaikan dengan model hipotesis, sebelumnya dilakukan uji validitas, uji reliabilitas, uji asumsi klasik dan uji linier berganda. Untuk mendukung hipotesis dilakukan uji determinasi, uji t dan uji f.

Dalam penelitian ini, variabel independen yang digunakan adalah : Efficiency $\left(X_{1}\right)$, Fulfillment $\left(X_{2}\right)$, Ketersediaan sistem $\left(X_{3}\right)$, Privacy $\left(X_{4}\right)$, Daya tanggap $\left(X_{5}\right)$, Kompensasi $\left(X_{6}\right)$ dan Kontak $\left(X_{7}\right)$ Sedangkan variabel dependennya adalah kepuasan 
nasabah (Y), sehingga persamaan regresi linier bergandanya adalah sebagai berikut (Ghozali, $2007: 85$ ):

$$
Y=\beta_{1} X_{1}+\beta_{2} X_{2}+\beta_{3} X_{3}+\beta_{4} X_{4}+\beta_{5} X_{5}+\beta_{6} X_{6}+\beta_{7} X_{7}+e
$$

\section{HASIL DAN PEMBAHASAN}

Dari hasil survey dan jawaban kuisioner diperoleh karakteristik responden sebagai berikut: jumlah responden terbanyak yaitu berada pada kelompok usia 26-50 tahun sebanyak 66 orang (66\%) sedangkan jumlah responden terkecil berada pada kelompok usia 15-25 tahun yaitu berjumlah 34 orang (34\%). Responden terbesar berpendidikan SLTA yaitu sebanyak 48 Orang (48\%), sedangkan yang terkecil yaitu yang berpendidikan SD dan SMP yakni sebanyak 4 orang (4\%). Jumlah responden terbanyak yaitu berada pada kelompok wirausaha sebanyak 39 orang (39\%) sedangkan jumlah responden terkecil berada pada kelompok pekerjaan 6 orang (6\%) pelajar/mahasiswa. Mayoritas responden memiliki status pekerjaan tetap 70 orang ( $70 \%)$ sedangkan yang paling kecil adalah dengan status pekerjaan pelajar/mahasiswa sebanyak 6 orang $(6 \%)$. Mayoritas responden memiliki rata-rata pendapatan per bulan antara Rp. 2.000.000 s/d Rp.5.000.000. Sedangkan responden yang memiliki persentase paling kecil ada responden dengan pendapatan $\geq 11.000 .0000$ dan sebagian besar telah menjadi nasabah Bank Bukopin Cabang Pontianak lebih dari 3 tahun lamanya yakni sebanyak 49 orang atau (49\%), sebagian besar responden juga menjadi nasabah bank lainnya, sebagian besar responden juga menjadi nasabah bank lainnya. Dan responden menggunakan layanan internet banking bank lain sebagian besar responden menggunakan layanan internet banking Bank Bukopin yakni untuk informasi rekening, transfer dan pembayaran tagihan.

\section{Uji Validitas}

Adapun hasil uji validitas pertanyaan-pertanyaan dalam variabel kualitas layanan internet banking dapat disimpulkan bahwa seluruh pertanyaan dalam variabel kualitas layanan internet banking dapat dinyatakan valid karena nilai $r$ hitung lebih besar dari $\mathrm{r}$ tabel. Pertanyaan yang memiliki validitas tertinggi adalah pertanyaan nomor 18 dengan nilai $\mathrm{r}$ hitung sebesar 0,884 dan pertanyaan yang memiliki validitas terendah adalah pertanyaan nomor 20 dengan nilai $\mathrm{r}$ hitung sebesar 
Internet

Banking;

Service

Quality

044

0,374. Sedangkan hasil uji validitas pertanyaan-pertanyaan dalam variabel kepuasan nasabah PT. Bank Bukopin Cabang Pontianak semua pertanyaan dalam variabel kepuasan nasabah PT. Bank Bukopin Cabang Pontianak dapat dinyatakan valid karena nilai $r$ hitung lebih besar dari $r$ tabel. Pertanyaan yang memiliki validitas tertinggi adalah pertanyaan nomor 2 dengan nilai $r$ hitung sebesar 0,650 dan pertanyaan yang memiliki validitas terendah adalah pertanyaan nomor 1 dengan nilai r hitung sebesar 0,482.

\section{Uji Reliabilitas}

Pengujian reliabilitas dilakukan dengan menggunakan teknik analisis Cronbach Alpha. Untuk menguji reliabilitas pada pertanyaan dalam variabel kualitas layanan internet banking, diketahui bahwa nilai cronbach's alpha adalah sebesar 0,963 dan jumlah pertanyaan adalah 21. Dengan demikian dapat disimpulkan bahwa kuesioner tersebut reliabel karena 0,963>0,60. Sedangkan untuk menguji reliabilitas pada pertanyaan dalam variabel kepuasan nasabah PT. Bank Bukopin Cabang Pontianak, nilai cronbach's alpha adalah sebesar 0,753 dan jumlah pertanyaan adalah 3. Dengan demikian dapat disimpulkan bahwa kuesioner tersebut reliabel karena 0,753>0,60.

\section{Uji Asumsi Klasik}

\section{a) Uji Linearitas}

Uji ini bertujuan untuk mengetahui apakah dua variabel mempunyai hubungan yang linier atau tidak secara signifikan. Pengujian Program SPSS 17.0 for Windows dengan menggunakan Test for Linearity dengan taraf signifikan 0,05. Menurut Priatno (2008 : 36), dua variable dikatakan mempunyai hubungan yang linear jika signifikansi (Linearity) kurang dari 0,05. Pada masing-masing variabel $X_{1}, X_{2}, X_{3}, X_{4}, X_{5}, X_{6}, X_{7}$ terhadap $Y$ menunjukan nilai linearitynya di bawah 0,05 artinya variabel masing-masing $\mathrm{X}$ terhadap $\mathrm{Y}$ mempunyai hubungan yang linear karena signifikansi (Linearity) kurang dari 0,05

\section{b) Uji Autokorelasi}

Uji autokorelasi bertujuan untuk menguji apakah dalam model regresi linear ada korelasi antara kesalahan pengganggu pada periode $t$ dan kesalahan 
penganggu pada periode sebelumnya (t-1). Apabila terjadi korelasi maka hal tersebut menunjukkan adanya problem autokorelasi (Sarjono dan Julianita, 2011: 84). Diketahui nilai DW berada diantara dU dan $4-\mathrm{dU}$, yaitu $1,8262<$

$2,148<2,4726$. Jadi dapat disimpulkan bahwa tidak terjadi autokorelasi.

\section{c) Uji Normalitas}

Uji normalitas bertujuan untuk menguji apakah dalam model regresi, variabel terikat, variabel bebas atau keduanya mempunyai distribusi normal atau tidak. Model regresi yang baik adalah memiliki distribusi data normal atau penyebaran data statistik pada sumbu diagonal dari grafik distribusi normal (Ghozali, 2005:97). diketahui bahwa titik-titik menyebar sekitar garis dan mengikuti garis diagonal, maka residual pada model regrsi tersebut terdistribusi secara normal

\section{d) .Uji Heterokedatisitas}

Uji heteroskedastisitas bertujuan untuk menguji apakah dalam model regresi terjadi ketidaksamaan varian dari satu pengamatan ke pengamatan yang lain (Ghozali, 2005:99). Diketahui bahwa titik-titik menyebar secara acak, baik dibagian atas angka nol atau dibagian bawah angka nol dari sumbu vertical atau sumbu kepuasan nasabah. Dengan demikian dapat disimpulkan bahwa tidak terjadi heterokedatisitas dalam model regresi ini.

\section{Analisis Regresi Linier Berganda}

Penelitian ini menggunakan alat analisis regresi linier berganda, yaitu analisis yang Berikut disajikan tabel hasil regresi linier berganda pengaruh efficiency $\left(\mathrm{X}_{1}\right)$, fulfillment $\left(\mathrm{X}_{2}\right)$, ketersediaan sistem $\left(\mathrm{X}_{3}\right)$, privacy $\left(\mathrm{X}_{4}\right)$, daya tanggap $\left(\mathrm{X}_{5}\right)$, kompensasi $\left(\mathrm{X}_{6}\right)$ dan kontak $\left(\mathrm{X}_{7}\right)$ terhadap kepuasan nasabah PT. Bank Bukopin Cabang Pontianak (Y):

Tabel 2 Hasil Analisis Regresi Linier Berganda

\begin{tabular}{|l|r|r|r|}
\hline \multicolumn{1}{|c|}{ Variabel } & Koefisien $(\beta)$ & \multicolumn{1}{c|}{ t hitung } & \multicolumn{1}{c|}{ Sig } \\
\hline Konstanta & & 10.038 & .000 \\
\hline Efisiensi & .455 & 2.251 & .027 \\
\hline Fulfillment & .221 & 1.995 & .049 \\
\hline Ketersediaan Sistem & .328 & 2.492 & .015 \\
\hline Privacy & -1.137 & -4.203 & .000 \\
\hline
\end{tabular}


Internet

Banking;

Service

Quality

046

\begin{tabular}{|l|r|r|r|}
\hline DayaTanggap & .322 & 2.092 & .039 \\
\hline Kompensasi & .955 & 3.388 & .001 \\
\hline Kontak & -398 & -2.955 & .004 \\
\hline $\mathrm{N}$ & $=100$ & \\
Koefisien Determinasi $\left(\mathrm{R}^{2}\right)$ & $=0,709$ \\
Koefisien Korelasi (r) & $=0,842$ \\
F Hitung & $=31,945$ \\
Sig F & $=0,000$ & \\
\hline
\end{tabular}

Sumber: Print Out SPSS

Berdasarkan Tabel 2 dapat diketahui masing-masing besarnya koefisien $\mathrm{X}_{1}$ dan $\mathrm{X}_{2}$, maka persamaan regresinya sebagai berikut:

$Y=0,455 X_{1}+0,221 X_{2}+0,328 X_{3}-(1,137) X_{4}+0,322 X_{5}+0,955 X_{6}-(0,398) X_{7}$

\section{Analisis Koefisien Korelasi (R)}

Nilai koefisien korelasi (R) yang diperoleh adalah sebesar 0,842. Menunjukkan hubungan antara efficiency, fulfillment, ketersediaan sistem, privacy, daya tanggap, kompensasi dan kontak terhadap kepuasan nasabah PT. Bank Bukopin Cabang Pontianak adalah sangat kuat positif karena berada pada rentang 0,800-1,000. Artinya jika nilai efficiency, fulfillment, ketersediaan sistem, privacy, daya tanggap, kompensasi dan kontak meningkat maka nilai kepuasan nasabah akan meningkat pula.

\section{Analisis Koefisien Determinasi $\left(\mathbf{R}^{\mathbf{2}}\right)$}

Nilai koefisien determinasi $\left(\mathrm{R}^{2}\right)$ yang diperoleh adalah sebesar 0,686. Artinya pengaruh efficiency, fulfillment, ketersediaan sistem, privacy, daya tanggap, kompensasi dan kontak terhadap variasi naik turunnya kepuasan nasabah PT. Bank Bukopin Cabang Pontianak adalah sebesar 68,60\%. Nilai 0,686 merupakan nilai dari Adjusted R Square karena variabel bebas/dependen dalam data lebih dari 2 variabel.

\section{Uji F}

Diketahui nilai F hitung > F tabel $(31,945>2,11)$, sehingga Ho ditolak. Cara lain untuk menentukan ketepatan model di atas, yaitu dengan membandingkan 
probabilitasnya. Jika probabilitas $>0,05$ maka model diterima dan jika probabilitasnya $<0,05$ maka model ditolak. Dapat dilihat nilai (sig) adalah 0,000< 0,05, berarti kualitas layanan internet banking yang terdiri dari efficiency, fulfillment, ketersediaan sistem, privacy, daya tanggap, kompensasi dan kontak secara bersama-sama memiliki pengaruh yang signifikan terhadap kepuasan nasabah PT. Bank Bukopin Cabang Pontianak.

\section{Uji Pengaruh Parsial (Uji t)}

Uji pengaruh parsial (uji t) dalam penelitian ini digunakan untuk mengetahui apakah berpengaruh signifikan pada variabel penelitian, berupa efficiency $\left(\mathrm{X}_{1}\right)$, fulfillment $\left(\mathrm{X}_{2}\right)$, ketersediaan sistem $\left(\mathrm{X}_{3}\right)$, privacy $\left(\mathrm{X}_{4}\right)$, daya tanggap $\left(\mathrm{X}_{5}\right)$, kompensasi $\left(\mathrm{X}_{6}\right)$ dan kontak $\left(\mathrm{X}_{7}\right)$ secara parsial (individu) terhadap kepuasan nasabah PT. Bank Bukopin Cabang Pontianak (Y). Berikut ditampilkan hasil penelitian pada tabel.

Tabel 3. Nilai t hitung Hasil Estimasi Regresi

\begin{tabular}{|l|l|c|c|l|}
\hline Pengaru & Beta & t hitung & Sig & Kesimpulan \\
\hline $\mathrm{X}_{1} \rightarrow$ & .455 & 2,251 & .027 & Ho ditolak Ha diterima \\
\hline $\mathrm{X}_{2} \rightarrow$ & .221 & 1,995 & .049 & Ho ditolak Ha diterima \\
\hline $\mathrm{X}_{3} \rightarrow$ & .328 & 2,492 & .015 & Ho ditolak Ha diterima \\
\hline $\mathrm{X}_{4} \rightarrow$ & -1.137 & $-4,203$ & .000 & Ho diterima Ha ditolak \\
\hline $\mathrm{X}_{5} \rightarrow$ & .322 & 2,092 & .039 & Ho ditolak Ha diterima \\
\hline $\mathrm{X}_{6} \rightarrow \mathrm{Y}$ & .955 & 3,388 & .001 & Ho ditolak Ha diterima \\
\hline $\mathrm{X}_{7} \rightarrow \mathrm{Y}$ & -.398 & $-2,955$ & .004 & Ho diterima Ha ditolak \\
\hline
\end{tabular}

Sumber: Data Olahan, Tahun 2019

\section{KESIMPULAN DAN SARAN}

\section{Kesimpulan}

Berdasarkan hasil analisis data dan pembahasan yang telah dilakukan, maka dapat ditarik kesimpulan sebagai berikut:

1. F-hitung > F-tabel $(31,945>2,11)$, sehingga Ho ditolak atau membandingkan probabilitasnya nilai (sig) adalah $0,000<0,05$, berarti kualitas layanan internet banking yang terdiri dari efficiency, fulfillment, ketersediaan sistem, privacy, daya tanggap, kompensasi dan kontak secara bersama-sama memiliki pengaruh yang signifikan terhadap kepuasan nasabah PT. Bank Bukopin Cabang Pontianak. 
Internet

Banking;

Service

Quality

048

2. Pengaruh efficiency $\left(\mathrm{X}_{1}\right)$ secara parsial (individu) terhadap kepuasan nasabah PT. Bank Bukopin Cabang Pontianak dapat dilihat nilai t hitung < tabel $(2,251<$ 1,98), sehingga Ho ditolak dan Ha diterima. Artinya, efficiency secara parsial berpengaruh signifikan terhadap kepuasan nasabah PT. Bank Bukopin Cabang Pontianak. Hal ini juga terlihat dari tingkat signifikansi variabel efficiency $\left(\mathrm{X}_{1}\right)$ sebesar 0,027 yang lebih kecil dari pada $0,05(0,027<0,05)$.

3. Pengaruh fulfillment $\left(\mathrm{X}_{2}\right)$ secara parsial berpengaruh signifikan terhadap kepuasan nasabah PT. Bank Bukopin Cabang Pontianak. Nilai t hitung > tabel (1,995 > 1,98), sehingga Ho ditolak dan Ha diterima. Artinya, fulfillment $\left(\mathrm{X}_{2}\right)$ secara parsial berpengaruh signifikan terhadap kepuasan nasabah PT. Bank Bukopin Cabang Pontianak (Y). Hal ini juga terlihat dari tingkat signifikansi variabel fulfillment $\left(\mathrm{X}_{2}\right)$ sebesar 0,049 yang lebih kecil dari pada $0,05(0,049<0,05)$.

4. Pengaruh ketersediaan sistem $\left(\mathrm{X}_{3}\right)$ secara parsial berpengaruh signifikan terhadap kepuasan nasabah PT. Bank Bukopin Cabang Pontianak. Nilai t hitung > tabel $(2,492>1,98)$, Ho ditolak dan Ha diterima. Artinya, ketersediaan sistem $\left(\mathrm{X}_{3}\right)$ secara parsial berpengaruh signifikan terhadap kepuasan nasabah PT. Bank Bukopin Cabang Pontianak (Y). Hal ini juga terlihat dari tingkat signifikansi variabel ketersediaan sistem $\left(\mathrm{X}_{3}\right)$ sebesar 0,015 yang lebih kecil dari pada 0,05 $(0,015<0,05)$

5. Pengaruh privacy $\left(\mathrm{X}_{4}\right)$ secara parsial berpengaruh negatif dan signifikan terhadap kepuasan nasabah PT. Bank Bukopin Cabang Pontianak. Nilai t hitung $=-4,203$ sedangkan $\mathrm{t}$ tabel sebesar $\pm 1,98$. Kesimpulannya: $-\mathrm{t}$ hitung < - tabel $(-4,203<-$ 1,98), sehingga Ho diterima dan Ha ditolak. Artinya, privacy $\left(\mathrm{X}_{4}\right)$ secara parsial berpengaruh negatif dan signifikan terhadap kepuasan nasabah PT. Bank Bukopin Cabang Pontianak (Y). Signifikan ini dapat dilihat dari tingkat signifikansi variabel privacy $\left(\mathrm{X}_{4}\right)$ sebesar 0,000 yang lebih kecil dari pada $0,05(0,000<0,05)$.

6. Pengaruh responsive $\left(\mathrm{X}_{5}\right)$ secara parsial berpengaruh signifikan terhadap kepuasan nasabah PT. Bank Bukopin Cabang Pontianak. Nilai t hitung > tabel (2,092 > 1,98), sehingga Ho ditolak dan Ha diterima. Artinya, responsive $\left(\mathrm{X}_{5}\right)$ secara parsial berpengaruh signifikan terhadap kepuasan nasabah PT. Bank Bukopin Cabang Pontianak (Y). Hal ini juga terlihat dari tingkat signifikansi variabel responsive/daya tanggap $\left(\mathrm{X}_{5}\right)$ sebesar 0,039 yang lebih kecil dari pada 
$0,05(0,039<0,05)$.

7. Pengaruh kompensasi $\left(\mathrm{X}_{6}\right)$ secara parsial berpengaruh signifikan terhadap kepuasan nasabah PT. Bank Bukopin Cabang Pontianak. Nilai t hitung > tabel $(3,388>1,98)$, sehingga Ho ditolak dan Ha diterima. Artinya, kompensasi $\left(\mathrm{X}_{6}\right)$ secara parsial berpengaruh signifikan terhadap kepuasan nasabah PT. Bank Bukopin Cabang Pontianak (Y). Hal ini juga terlihat dari tingkat signifikansi variabel kompensasi $\left(\mathrm{X}_{6}\right)$ sebesar 0,001 yang lebih kecil dari pada 0,05 $(0,001<0,05)$.

8. Pengaruh kontak $\left(\mathrm{X}_{7}\right)$ secara parsial berpengaruh negatif dan signifikan terhadap kepuasan nasabah PT. Bank Bukopin Cabang Pontianak. Nilai t hitung $=-2,955$ sedangkan $t$ tabel sebesar $\pm 1,98$. Kesimpulannya: $-t$ hitung $<-$ tabel $(-2,955<-1,98)$, sehingga Ho diterima dan Ha ditolak. Artinya, kontak $\left(\mathrm{X}_{7}\right)$ secara parsial berpengaruh negatif dan signifikan terhadap kepuasan nasabah PT. Bank Bukopin Cabang Pontianak (Y). Signifikan ini dapat dilihat dari tingkat signifikansi variabel kontak $\left(\mathrm{X}_{7}\right)$ sebesar 0,004 yang lebih kecil dari pada $0,05(0,004<0,05)$.

\section{Saran}

Berdasarkan temuan penelitian, maka dapat disimpulkan beberapa saran sebagai berikut:

1. Dalam meningkatkan kepuasan nasabah perlunya bank lebih meningkatkan privacy perbankan karena masih ada sebagian kecil masyarakat tersugesti bahwa bank keamanan bank di Indonesia pada umum masih bisa dibobol seperti pencurian lewat transaksi belanja online menggunakan rekening orang lain dan pembobolan lewat ATM.

2. Dalam upaya meningkatkan kepuasan nasabah internet banking, perlunya meningkatkan kualitas pelayanan kontak, karena biasanya cukup sulit menghubungi pihak bank karena jalur telepon yang dihubungi sering sibuk.

3. Dalam upaya meningkatkan kepuasan nasabah internet banking, maka langkah yang dapat ditempuh oleh bank adalah melalui peningkatan kualitas layanan fulfillment, mencakup akurasi janji layanan, ketersediaan stok produk, dan pengiriman produk sesuai dengan waktu yang dijanjikan.

4. Dalam upaya meningkatkan kepuasan nasabah internet banking maka langkah layanan yang perlu ditingkatkan adalah semakin melengkapi fitur-fitur layanan 
Internet

Banking;

Service

Quality

internet banking dengan demikian akan meningkatkan kepuasan nasabah dalam menggunakan fasilitas tersebut.

5. Bagi peneliti lain yang berminat melakukan kajian ulang terhadap penelitian ini, diharapkan dapat melakukan pengembangan dan perbaikan terhadap penelitian ini. Perbaikan dan pengembangan tersebut dapat dilakukan melalui: penambahan beberapa variabel lain seperti variabel trust dan loyality sebagai variabel dependentnya, serta menggunakan responden yang lebih banyak.

\section{DAFTAR PUSTAKA}

Akbar, M. M., dan Parvez, N., 2009, Impact of Service Quality, Trust, and Customer Satisfaction on Customer Loyalty, ABAC Journal, 29( 1), pp 24 -38

Annual report PT. Bank Bukopin, Tbk, 2012. Annual report PT. Bank Bukopin, Tbk, 2013.

Fandy Tjiptono, Gregorius Chandra \& Dadi Adriana., 2008, Pemasaran Strategik, Yogyakarta: Penerbit Andi.

Ghozali, Imam., 2005, Aplikasi Analisis Multivariate dengan Program SPSS, Semarang: Badan Penerbit Universitas Diponogoro.

Ghozali, Imam. 2005. Aplikasi Analisis Multivariate dengan program SPSS, Semarang: Badan Penerbit Universitas Diponegoro.

Hadi, Sutrisno., 2004. Metodologi Research, Jilid 3. Yogyakarta : Andi.

Jajuk Herawati dan Prayekti, 2011, Pengaruh dimensi internet banking service quality dan kepercayaan nasabah terhadap kepuasan nasabah. (Penelitian Empiris terhadap Nasabah Internet Banking di Kota Yogyakarta), Akmenika, Vokume 8, UPY.

Kotler, Philip., 2002, Manajemen Pemasaran edisi Millennium dua, Jakrta: PT. Prenhallindo.

Kotler, Philip dan Gary Armstrong., 2008, Prinsip-prinsip Pemasaran (judul asli: Principles of Marketing), edisi kedua belas, jilid 1. Penerjemah Bob Sabran, 
Jakarta: Erlangga.

Kotler, Philip dan Gary Armstrong., 2010. Principles of Marketing. 13th Edition,

Kotler, Philip dan Kevin Lane Keller., 2009. Manajemen Pemasaran (judul asli: Marketing Management), edisi ketiga betas, jilid 1. Penerjemah Bob Sabran. Jakarta: Erlangga.

Kotler, Philip., 2002. Manajemen Pemasaran, Analisa perencanaan, Implementasi dan kontrol, Edisi Kesembilan, Jilid 1 dan jilid 2, alih bahasa oleh Hendra Teguh S.E.,A.K., dan Ronny A. Rusli, S.E., Jakarta, Prehalindo.

Kotler,Philip \& Kevin Lane Keller., 2008, Manajemen Pemasaran, Jakarta : Indeks

Lupiyoadi, Rambat dan A. Hamdani., 2006, Manajemen Pemasaran Jasa, edisi kedua. Jakarta: Salemba Empat.

Martono., 2010, Bank dan Lembaga Keuangan Lain, Yogyakarta : Ekonisia.

Monalisa, Siti dan Erma Suryani., 2013, Pengaruh kualitas layanan internet banking terhadap kepuasan daan loyalitas nasabah bank dengan menggunakan sistem dinamik. Surabaya : Institut Teknologi Sepuluh November.

Nurastuti, Wiji., 2011, Teknologi Perbankan, Yogyakarta: Graha Ilmu.

Parasuraman, Leonard L. Berry, And Valarie A. Zeithml. 1985. A Conceptual Model Of Services Quality And Its Implications For Future Research, Journal Of Marketing, Vol. 49, P.41-50

Parasuraman et al, 2005, Relationship Between Online Service Quality And Customer Satisfaction. A Study in Internet Banking, Department of Bussines Administration and Social Sciences Division Of Industrial Marketing and ecommerce, Lulea University Of Tecnology.

Peraturan Bank Indonesia No. 9/15/PB1/2007 Tahun 2007 tentang Penerapan Manajemen Risiko Dalam Penggunaan Teknologi Informasi oleh Bank Umum, Palembang: Univeritas IBA. 
Internet

Banking; Service

Zeithaml, Bitner, Gremler., 2006, Services Marketing: Integrating Customer Focus Quality Across The Firm, Singapore: The MCGraw-Hill Companies.

Zeithaml, et al. 2002, Service Quality Delivery Through Web Sites: A Critical Review of Extant Knowledge, Academy of Marketing Science. 